\title{
Combining radiation therapy with immunotherapy: clinical translation
}

\author{
Silvia C Formenti \\ From Melanoma Bridge Meeting 2014 \\ Naples, Italy. 03-06 December 2014
}

Ionizing radiation induces immunogenic cell death of tumors, an effect likely to contribute to the success associated with radiotherapy of cancer [1]. Recent discovery suggests that radiotherapy can be applied as a powerful adjuvant to immunotherapy and, in fact, can contribute to convert the irradiated tumor into an in situ vaccine, resulting in specific immunity against metastases [2]. Preclinical models of syngeneic tumors have reliably predicted clinical success, in distinct tumor settings and immunotherapy/radiation combinations [3-5]. As a first proof of principle trial, we translated the preclinical evidence of a successful combination with Flt3 ligand and RT [6] to a protocol of GM-CSF and RT, and demonstrated out of field objective responses in $27 \%$ of patients with multiple metastases of solid tumors, defined as an abscopal effect [7]. Parallel mechanistic studies in the lab in the syngeneic $4 \mathrm{~T} 1$ mouse model of metastatic breast cancer demonstrated at intratravital microscopy that RT with anti-CTLA-4 increased the arrest of T cells in contact with tumor cells. The latter required interaction of NKG2D on CD8 + T cells with its ligand retinoic acid early inducible-1 (Rae-1) on the tumor cells, up-regulated by RT. Blocking NKG2D-Rae-1 interactions increased markedly the motility of anti-CTLA-4 treated T cells inhibiting their contact with irradiated tumor cells, and abrogated immune-mediated tumor rejection, suggesting a critical role of radiation-induced NKG2D ligands for the antitumor effects of anti-CTLA-4 [8]. In humans, a similar block of NKG2D is mediated by soluble MICA (sMICA), which is released by some tumors and reaches high levels in the serum [9]. Dranoff et al reported that in some patients sMICA levels dropped after initiation of Ipilimumab, due to the generation of anti-sMICA antibodies that led to its clearance [10]. Decreased levels of

Department of Radiation Oncology and Medicine, New York University School of Medicine and New York University Perlmutter Cancer Institute, New York, New York, USA 
Roman RA, Rosner S, Benson B, Allison JP, Lesokhin AM, Gnjatic S,

Wolchok JD: Immunologic correlates of the abscopal effect in a patient with melanoma. N Engl J Med 2012, 366:925-931.

5. Golden EB, Demaria S, Schiff PB, Chachoua A, Formenti SC: An abscopal response to radiation and ipilimumab in a patient with metastatic nonsmall cell lung cancer. Cancer immunology research 2013, 1(6):365-372.

6. Demaria S, Ng B, Devitt ML, Babb JS, Kawashima N, Liebes L, Formenti SC: lonizing radiation inhibition of distant untreated tumors (abscopal effect) is immune mediated. Int I Radiat Oncol Biol Phys 2004, 58(3):862-870.

7. Formenti SC, Demaria S: Systemic effects of local radiotherapy. Lancet Oncol 2009, 10(7):718-726.

8. Ruocco MG, Pilones KA, Kawashima N, Cammer M, Huang J, Babb JS, Liu M, Formenti SC, Dustin ML, Demaria S: Suppressing T cell motility induced by anti-CTLA-4 monotherapy improves antitumor effects. J Clin Invest 2012, 122(10):3718-3730.

9. Groh V, Wu J, Yee C, Spies T: Tumour-derived soluble MIC ligands impair expression of NKG2D and T-cell activation. Nature 2002, 419(6908):734-738.

10. Jinushi M, Hodi FS, Dranoff G: Therapy-induced antibodies to MHC class I chain-related protein $A$ antagonize immune suppression and stimulate antitumor cytotoxicity. Proc Natl Acad Sci U S A 2008, 103(24):9190-9195.

11. Gasser S, Orsulic S, Brown EJ, Raulet DH: The DNA damage pathway regulates innate immune system ligands of the NKG2D receptor. Nature 2005, 436(7054):1186-1190.

doi:10.1186/1479-5876-13-S1-K10

Cite this article as: Formenti: Combining radiation therapy with

immunotherapy: clinical translation. Journal of Translational Medicine 2015

13(Suppl 1):K10.

\section{Submit your next manuscript to BioMed Central} and take full advantage of:

- Convenient online submission

- Thorough peer review

- No space constraints or color figure charges

- Immediate publication on acceptance

- Inclusion in PubMed, CAS, Scopus and Google Scholar

- Research which is freely available for redistribution

Submit your manuscript at www.biomedcentral.com/submit 